\title{
PARTICLE SIZE ANALYSIS OF TWO DISTINCT Classes of WHEAT FlOUR BY SiEVING
}

\author{
A. Patwa, B. Malcolm, J. Wilson, R. P. K. Ambrose
}

\begin{abstract}
The most commonly used method for particle size analysis of wheat flour in the grain industry is a sieve shaker following either the ASABE or AACC standard. This study involved the determination of mean particle size of flour from two different classes of wheat, hard red winter $(H R W)$ and soft white $(S W)$, at sieving times of 8, 10, 12, 14, 16, and 18 min. Particle size measured by sieve analysis was compared with size as measured using laser diffraction. It was found that sieving time and wheat class had a significant effect on the measured final particle size. Increase in sieving time reduced the calculated average particle size of the flour. The mean particle size for HRW and SW flour was $110.98 \mu \mathrm{m}$ and $570.29 \mu \mathrm{m}$, respectively, at $14 \mathrm{~min}$ of sieving. The mean particle size as measured by laser diffraction was $45.6 \mu \mathrm{m}$ and $44.5 \mu \mathrm{m}$ for HRW and SW flour, respectively. A flow agent helped the flour particles overcome the interparticle cohesive force during sieving and resulted in a smaller particle size with better size distribution. However, due to the higher cohesiveness of SW flour, flow agent at $0.5 \%$ of the sample mass had no effect on the measured mean particle size. Weibull and log-normal equations predicted the size distribution of flour with lower percent relative deviation compared to the RosinRammler and Kumaraswamy equations.
\end{abstract}

Keywords. Particle size, Particle size distribution, Size distribution function, Wheat flour.

W heat milling is a progressive size-reduction process in which the wheat endosperm is gradually milled to a specific size range of flour. Per the U.S. Code of Federal Regulations (CFR, 2013) for cereal flours and related products, for classifying the end product of the milling process as flour, "not less than 98 percent of the flour passes through a cloth having openings not larger than those of woven wire cloth designated $212 \mu \mathrm{m}$ (No. 70)." In general, particle size is an important quality parameter of flour that greatly affects the processing techniques and end product quality, especially in the case of wheat flour (Sullivan et al., 1960). Different techniques are used for powder particle size determination, including sieve analysis, sedimentation, microscopy, Coulter Counter, laser diffraction, and near-infrared reflectance spectroscopy (Hareland, 1994). Except for sieve analysis, although accurate, these methods are limited to analytical laboratories due to the cost and measurement time involved. Particle size measurement of wheat flour by sieving, using a Ro-Tap sieve shaker, is more commonly employed by industry for its simplicity and ease of analysis,

Submitted for review in August 2013 as manuscript number FPE 10388; approved for publication by the Food \& Process Engineering Institute of ASABE in December 2013.

Contribution No. 14-072-J of the Kansas State University Agricultural Experiment Station.

The authors are Abhay Patwa, ASABE Member, Graduate Student, Blake Malcolm, Graduate Student, Jonathan Wilson, Graduate Student, and R. P. Kingsly Ambrose, ASABE Member, Assistant Professor, Department of Grain Science and Industry, Kansas State University, Manhattan, Kansas. Corresponding author: R. P. Kingsly Ambrose, 201 Shellenberger Hall, Kansas State University, Manhattan, KS 66506; phone: 785-532-4091; e-mail: kingsly@k-state.edu. and for its similarity to the wheat mill sifting process.

For particle size determination of wheat flour, ASABE Standard S319.4 (ASABE Standards, 2008) and AACC Standard 55-60.01 (AACC, 2011) are the most commonly followed methods. ASABE Standard S319.4 specifies a sieving time of $10 \mathrm{~min}$ for analytical purposes $(15 \mathrm{~min}$ for industrial purposes) and an increment of 1 min until the mass on the smallest sieve (excluding the pan) changes by $0.1 \%$. ASABE Standard S319.4 also states that the particle size may be determined with or without the addition of a flow agent. Similarly, the AACC standard mentions a sieving time of 5 to $15 \mathrm{~min}$ depending on the particle size of the product (longer times for smaller particle sizes). In the AACC method, size is measured based on the sample that passes through a single sieve, rather than using data from a set of sieves to calculate the average size. Wu et al. (1990) reported that the use of a set of sieves results in more accurate mean particle size compared to using a single screen.

Commercial wheat varieties are generally classified as hard or soft based on their kernel hardness. Milling behavior, flour particle size, flour particle size distribution, and flour functionality are influenced by the hardness of the wheat kernels. Wheat hardness is negatively correlated with flour yield (Martin et al., 2001), and the flour particle size depends on the hardness of the wheat (Pauly et al., 2013). Due to the weaker bonding between starch and protein, milling soft wheat results in smaller particle sizes (Bechtel et al., 1993; Pauly et al., 2013) than hard wheat. The difference in hardness values results from hard wheat having starch granules that are deeply embedded within the protein matrix of the kernel's endosperm, while soft wheat contains voids in the endosperm protein matrix in which the starch granules are weakly embedded (Turnbull and 
Rahman, 2002). This results in soft wheat's milling into flours that have smaller average particle sizes when compared to hard wheat flours (Kim et al., 2004). Hareland (1994) reported that soft wheat flour experiences high cohesion and clogs the sifter screens, which results in conflicting mean particle size results when compared to those obtained by laser diffraction techniques. To overcome the cohesive forces between particles during size measurement, ASABE Standard S319.4 suggests the use of flow agents (ASABE Standards, 2008). Irani and Fong (1961) found that the measurement accuracy of flour particle size increased with the use of the flow agent tricalcium phosphate (at $1 \%$ ) during sieving.

Size reduction of wheat kernels depends on the wheat's physical characteristics, such as kernel size, density, and hardness, and on the roller mill's operational parameters. The breakage patterns of hard and soft wheat are different, and the resultant mathematical distribution function calculated based on the particle size distribution could be used to predict the milling performance (Campbell et al., 2001). Different distribution functions are used to characterize size-reduction processes mathematically by interpreting the physical parameters derived from the resultant particle size distributions. These parameters help in modeling the sizereduction process. Because these parameters are calculated from the particle size distribution, the method of size measurement highly influence the resulting distribution function. This research focuses on the differences in particle size and size distribution of hard red winter wheat flour and soft white wheat flour when performed using a Ro-Tap sieve shaker. These two wheat classes were selected for their contrasting kernel hardness and for their extreme compositional differences within the six U.S. wheat classes.

The overall objective of this study was to evaluate the method of particle size determination by sieving as affected by flour type, time of sieving, and flow agent addition. The specific objectives were to: (1) evaluate the change in average flour particle size due to change in sieving time and presence of flow agent, (2) describe the difference in particle size distribution of hard and soft wheat flour as influenced by sieving time, and (3) calculate the size distribution functions at different sieving times.

\section{MATERIALS ANd Methods \\ SAMPLES}

Commercially manufactured hard red winter (HRW) and eastern soft white (SW) wheat flour was obtained from two different cooperating industries. The HRW flour samples were obtained from Conagra Mills, Decatur, Alabama, and the SW flour was obtained from The King Milling Company, Lowell, Michigan. The tempering moisture contents of the HRW and SW wheat were $16.5 \%$ and $14.5 \%$ (wet basis), respectively. The milling companies both used seven break rolls and 12 reduction rolls in the milling process. The first break extraction rate was maintained in the range of $36 \%$ to $40 \%$ flour extraction. The difference between the milling processes was in the higher sifter surface used during the SW milling process. The flour samples were col- lected before adding enrichment or additives and shipped for storage at Kansas State University, Manhattan, Kansas. The flour samples were stored at $-5^{\circ} \mathrm{C}$ until the experiments. The moisture content of the flour was determined using AOAC Standard 925.10 (AOAC, 2000) by drying 2 to $3 \mathrm{~g}$ of the sample in a hot-air oven at $130^{\circ} \mathrm{C}$ for $60 \mathrm{~min}$.

\section{Single Kernel CharaCterization System}

Wheat kernels were also obtained from the same flour milling facilities for single kernel characterization system (SKCS) analysis to determine the hardness of the wheat. A wheat hardness testing instrument (model SKCS 4100, Perten Instruments, Hägersten, Sweden) was used. The wheat kernel samples were cleaned by removing broken kernels, weed seeds, and other foreign material, and 12 to $16 \mathrm{~g}$ of sample per replication was used for SKCS analysis. The Perten instrument analyzes 300 kernels individually for kernel weight, diameter, moisture content, and hardness. Mean and standard deviations of these parameters were reported as SKCS results in this study.

\section{Flour Particle Size and Size Distribution}

Geometric mean diameter and particle size distribution of the flour samples were determined according to ASABE Standard S319.4 (ASABE Standards, 2008). Flour (100 g) was placed on the topmost sieve of a nest of sieves of successively decreasing apertures. The sieves (U.S. series) used were numbers $6,8,12,16,20,30,40,50,70,100$, $140,200,270$, and the pan. The empty weight of each sieve was recorded before sieve analysis. The nest of test sieves was shaken for $8,10,12,14,16$, and $18 \mathrm{~min}$ in a sieve shaker (Ro-Tap model RX-29, W.S. Tyler, Mentor, Ohio), after which the mass of sample retained on each sieve was recorded. The sieving times were selected based on the ASABE and AACC standards. To assist the flow of flour through the nest of sieves, a sieve cleaner nipple and an ivory rubber ball $(39 \mathrm{~mm})$ were placed on each of sieve numbers $12,16,20,30$, and 40, a dual cleaner with nylon brushes was placed on sieve numbers 50, 70, 100, and 140, and a dual cleaner with nylon brushes and a cube cleaner was placed on sieve number 200 .

The geometric mean diameter $\left(d_{g w}\right)$ of the wheat flour and the geometric standard deviation of the particle diameter $\left(S_{g w}\right)$ were calculated using the following equations:

$$
\begin{gathered}
d_{g w}=\log ^{-1}\left[\frac{\sum_{i=1}^{n}\left(W_{i} \log \overline{d_{i}}\right)}{\sum_{i=1}^{n} W_{i}}\right] \\
S_{g w}=\frac{1}{2} d_{g w}\left[\log ^{-1} S_{l o g}-\left(\log ^{-1} S_{l o g}\right)^{-1}\right]
\end{gathered}
$$

where $d_{g w}$ is the geometric mean diameter of the particles by mass $(\mathrm{mm}), S_{l o g}$ is the geometric standard deviation of the log-normal distribution by mass, $S_{g w}$ is the geometric standard deviation of the particle diameter by mass $(\mathrm{mm})$, $W_{i}$ is the mass on the $i$ th sieve $(\mathrm{g}), n$ is the number of sieves, and $d_{i}$ is the nominal sieve aperture size of the $i$ th sieve (mm).

Sieve analysis was repeated by adding a flow agent to 
the samples to reduce cohesion and clogging of the sieves during size measurement. Flow agents reduce interparticle forces, reducing cohesiveness and aiding in separation of particles, making them more free flowing (Onwulata et al., 1996). The ASABE and AACC standards suggest a maximum of 15 min of sieve analysis. Because this study was conducted in 2 min increments, 14 min of sieving was selected for testing with the addition of the flow agent. ASABE Standard 319.4 (ASABE Standards, 2008) indicates that the maximum amount of flow agent that can be used is $0.5 \%$ of the total mass of the sample. Cabosil $(0.5 \%$ by weight), a synthetic amorphous precipitated silica, was used as the flow agent for analysis of HRW and SW flour based on Nielsen et al. (1982), who found that adding Cabosil at $0.5 \%$ reduced the agglomeration tendencies of wheat flour during processing. In this study, the flow agent was mixed with the flour sample in a glass beaker using handheld stirrers before sieve analysis.

For comparing the measured particle sizes, size analysis was also performed using laser diffraction (LA-910, Horiba, Ltd., Kyoto, Japan) to calculate the average particle size and size distribution based on volume distribution. The samples were diluted $(2 \mathrm{~mL}$ in $20 \mathrm{~mL})$ by mixing with deionized water and agitated by a set of agitating blades at $400 \mathrm{rpm}$. Agitation was performed to ensure proper dilution of the sample in the distilled water. To break down aggregated flour particles and remove air bubbles, the instrument uses ultrasonic vibrations $(39 \mathrm{kHz})$ after agitation. A similar method was used by Kim et al. (2004) to measure the effect of heating temperature on the particle size distribution of wheat flour.

\section{Mathematical Distribution FunCtions}

Particle size distributions can be represented in mathematical form by using probability density functions or cumulative distribution functions (Khazaei et al., 2008). Rosin-Rammler, Weibull, Kumaraswamy, and log-normal distribution functions are commonly used to describe the breakage behavior of granular materials (Limpert et al., 2001; Lu et al., 2007; Mateos-Salvador et al., 2011; Alderliesten, 2013). These probability distribution functions (eqs. 3 through 6) have been used to predict the size distribution of powder materials in a broad range of particle sizes (Weibull, 1951; Alderliesten, 2013).

\section{Rosin-Rammler Distribution Function}

$$
R(x)=\exp \left(-\frac{D}{D_{n}}\right)^{n}
$$

where $R$ is the cumulative mass fraction retained on sieve of opening size $D, D$ is the sieve opening or particle diameter in microns, $D_{n}$ is the size parameter, and $n$ is the distribution parameter.

\section{Weibull Distribution Function}

$$
f(x)=\frac{\alpha}{\beta}\left(\frac{x}{\beta}\right)^{\alpha-1} \exp \left(-\left(\frac{x}{\beta}\right)^{\alpha}\right)
$$

where $x$ is the particle size, $\alpha$ is the slope or shape parameter $(\alpha>0)$, and $\beta$ is the scale parameter $(\beta>0)$.

\section{Kumaraswamy Distribution Function}

$$
\begin{gathered}
f(x)=\frac{\alpha_{1} \alpha_{2} z^{\alpha_{1}-1}\left(1-z^{\alpha_{1}}\right)^{\alpha_{2}-1}}{(b-a)} \\
z=(x-a) /(b-a)
\end{gathered}
$$

where $x$ is the particle size, $\alpha_{1}$ is a shape parameter $\left(\alpha_{1}>\right.$ $0), \alpha_{2}$ is a shape parameter $\left(\alpha_{2}>0\right)$, and $a$ and $b$ are the continuous boundary parameters $(a<b)$.

\section{Log-Normal Distribution Function}

$$
f(x)=\frac{1}{\sqrt{2 \pi \sigma^{2}}} \exp \left[-\frac{(\ln [x]-\mu)^{2}}{2 \sigma^{2}}\right]
$$

where $x$ is the particle size, $\mu$ is the mean, and $\sigma^{2}$ is the variance

Each of these functions was evaluated and compared to determine the suitable prediction equation that could explain the particle size distribution of the flour varieties evaluated. EasyFit 5.5 Professional (Mathwave Technologies, Dnepropetrovsk, Ukraine) was used to evaluate the distribution functions from the particle size distribution data.

\section{Data ANALYSIS}

A completely randomized experimental design was used to analyze the particle size of wheat flour at six different time intervals ranging from 8 to $18 \mathrm{~min}$. All tests were performed in triplicate. Results from each test were analyzed for statistical significance using SAS (ver. 9.3, SAS Institute, Inc., Cary, N.C.). The particle sizes of HRW and SW flours obtained from each sifting were compared with each other and with those obtained from laser diffraction using Tukey's honestly significant difference test in SAS. The mean relative percent deviation $(P)$ was calculated using equation 7 to compare the performance of the particle breakage models:

$$
P=\frac{100}{N} \times \sum \frac{\left|Y-Y_{p}\right|}{Y}
$$

where $Y$ is the measured value, $Y_{p}$ is the predicted value, and $N$ is the number of data points.

\section{RESUltS AND DiscuSSION \\ Single KeRNEL CHARACTERIZATION}

The hardness index of the HRW wheat was over 3.5 times greater than that of the SW wheat (table 1). The harder the individual kernel, the more brittle it will be when subjected to the crushing forces between break rolls during the milling process. This results in an easier break and more consistent particle size reduction from the lead rolls. In hard wheat, higher hardness indicates that the cell con- 
Table 1. Wheat kernel characteristics. ${ }^{|\mathrm{a}|}$

\begin{tabular}{cccc}
\hline Sample & $\begin{array}{c}\text { Hardness } \\
\text { Index }\end{array}$ & $\begin{array}{c}\text { Weight } \\
(\mathrm{mg})\end{array}$ & $\begin{array}{c}\text { Diameter } \\
(\mathrm{mm})\end{array}$ \\
\hline Hard red winter wheat & $64.55 \mathrm{a}$ & $29.70 \mathrm{a}$ & $2.60 \mathrm{a}$ \\
& $(16.12)$ & $(9.13)$ & $(0.38)$ \\
\hline Soft white wheat & $18.16 \mathrm{~b}$ & $35.10 \mathrm{a}$ & $2.67 \mathrm{a}$ \\
& $(16.71)$ & $(10.13)$ & $(0.38)$ \\
\hline
\end{tabular}

Means in the same column followed by the same letter are not significantly different $(\mathrm{p} \geq 0.05)$. Standard deviations shown in parentheses.

tents are integrated very tightly within the wheat kernel (Turnbull and Rahman, 2002). Although the weights of individual kernels varied, the sizes of kernels (diameter) were not significantly different. Moisture content of the HRW and SW wheat flour was $11.0 \%$ and $11.4 \%$ (w.b.), respectively.

\section{Particle Size and Size Distribution Analysis}

Particle size of wheat flour, measured as the geometric mean particle diameter, is a critical factor in determining the flour's usefulness and application in further processing and in baking. In this study, particle size analysis results were compared for the two flour classes within each sieving time as well as between sieving times within each wheat class. Increases in sieving time reduced the geometric particle size (table 2) for both HRW and SW wheat flours. There was a significant difference $(p<0.05)$ between particle sizes for both flour types at all corresponding sieving times. However, this comparison is irrelevant because the particle size measurements of SW flour did not yield accurate results. This indicates that the sieving time of 15 min suggested by the ASABE and AACC standards does not give the actual geometric mean diameter of flour particles. Increased tapping time might have helped in breaking down the cohesive flour particle aggregates and assisted the flow through the sieves. The particle size for SW flour using the Ro-Tap sieve shaker was extraordinarily high (table 2) and well above the acceptable limits (CFR, 2013). Neel and Hoseney (1984) indicated that the sieving index of SW flour is very low and reduces the throughput in industrial processing. During the sieve analysis of SW flour, the bulk of the flour was retained between the U.S. No. 16 $(1680 \mu \mathrm{m})$ and No. $20(841 \mu \mathrm{m})$ sieves. The flour particles agglomerated and lodged in the screen openings, preventing any further material from passing through. A similar phenomenon of flour agglomeration during sieving was observed by Hareland (1994). The cohesive nature of SW flour particles, resulting from the lack of structure when compared to HRW wheat, increased agglomeration during sieving (Turnbull and Rahman, 2002). Table 2 also shows the particle sizes for the two wheat flour types obtained by laser diffraction. There was no significant difference $(\mathrm{p}<$ 0.05 ) in the mean particle size of the two flour types obtained by laser diffraction. However, when the particle size obtained by laser diffraction is compared to that obtained by sieve analysis (with or without a flow agent), there was a significant difference in the particle sizes between the two methods.

Figures 1 and 2 present the cumulative distributions of HRW and SW flours at different sieving times. For HRW flour, the distribution became narrower with increases in sieving time, but the distribution remained unimodal irrespective of time. Increased sieving time reduced the particle size of HRW flour but did not alter the distribution (fig. 1). Irrespective of sieving time, $85 \%$ to $90 \%$ of the HRW flour was retained above a U.S. No. $40(420 \mu \mathrm{m})$ sieve at $8 \mathrm{~min}$ and above a U.S. No. $100(149 \mu \mathrm{m})$ sieve at $18 \mathrm{~min}$ of sieving. For SW flour, there was a substantial difference in the particle size distribution with increased sieving time ( 8 to $18 \mathrm{~min}$ ) (fig. 2 ). The inaccurately high particle diameter values for SW flour can be seen in the average particle sizes (table 2). At 16 and $18 \mathrm{~min}$ of sieving, a bimodal particle size distribution was observed for SW flour. The smaller modes are the starch granules, while the other non-starch components form the second wider distribution (Lineback and Rasper, 1988). At $8 \mathrm{~min}, 90 \%$ of the flour was retained above a U.S. No. $16(1190 \mu \mathrm{m})$ sieve, while at $18 \mathrm{~min}$ of sieving, $90 \%$ of the flour was retained above a U.S. No. $20(841 \mu \mathrm{m})$ sieve. SW flour has a slightly wider distribution at the lower end, probably due to the presence of disassociated starch granules, which is a consequence of starch-protein disaggregation compared to HRW flour.

The sieve analysis was repeated for both flour classes with the addition of $0.5 \mathrm{~g}$ of flow agent. Preliminary tests indicated that this quantity of flow agent was insufficient for SW flour (results not shown), as it did not influence the average particle size and the size distribution. Neel and Hoseney (1984) hypothesized that a higher concentration of flow agent might be required for an accurate particle size determination of SW flour. In fact, a more accurate size distribution was obtained when $2.5 \mathrm{~g}$ of flow agent was used and the flour sample was placed on top of the U.S. No. $40(420 \mu \mathrm{m})$ sieve. By addition of a flow agent, cohesive particles overcome the flow issues caused by particle surface roughness. Because the surface roughness of SW flour is higher than that of HRW flour, more flow agent is

Table 2. Geometric mean particle diameter $\left(d_{g_{w}}, \mu \mathrm{m}\right)$ and standard deviation $\left(S_{g_{w}}, \mu \mathrm{m}\right)$ of wheat flour as influenced by sieving time. ${ }^{\text {[a] }}$

\begin{tabular}{|c|c|c|c|c|c|c|c|c|c|c|c|c|}
\hline \multicolumn{12}{|c|}{ Sieving Time } & \multirow{3}{*}{$\begin{array}{c}\text { Laser } \\
\text { Diffrac- } \\
\text { tion }\end{array}$} \\
\hline \multicolumn{2}{|c|}{$8 \mathrm{~min}$} & \multicolumn{2}{|c|}{$10 \mathrm{~min}$} & \multicolumn{2}{|c|}{$12 \mathrm{~min}$} & \multicolumn{2}{|c|}{$14 \mathrm{~min}$} & \multicolumn{2}{|c|}{$16 \mathrm{~min}$} & \multicolumn{2}{|c|}{$18 \mathrm{~min}$} & \\
\hline$d_{g w}$ & $S_{g w}$ & $d_{g w}$ & $S_{g w}$ & $d_{g w}$ & $S_{g w}$ & $d_{g w}$ & $S_{g w}$ & $d_{g w}$ & $S_{g w}$ & $d_{g w}$ & $S_{g w}$ & \\
\hline \multicolumn{13}{|c|}{ Hard red winter wheat flour } \\
\hline $\begin{array}{c}161.49 \mathrm{~A} \\
(2.43)\end{array}$ & $\begin{array}{c}128.91 \mathrm{a} \\
(4.71)\end{array}$ & $\begin{array}{c}142.30 \mathrm{~B} \\
(12.37)\end{array}$ & $\begin{array}{c}105.94 \mathrm{ab} \\
(14.98)\end{array}$ & $\begin{array}{c}120.76 \mathrm{C} \\
(4.31)\end{array}$ & $\begin{array}{c}90.00 \mathrm{bc} \\
(12.15)\end{array}$ & $\begin{array}{c}111.98 \mathrm{CD} \\
(3.68)\end{array}$ & $\begin{array}{c}81.05 \mathrm{bc} \\
(8.68)\end{array}$ & $\begin{array}{c}105.76 \mathrm{CD} \\
(2.17)\end{array}$ & $\begin{array}{c}81.91 \mathrm{bc} \\
(4.15)\end{array}$ & $\begin{array}{c}100.14 \mathrm{D} \\
(3.46)\end{array}$ & $\begin{array}{l}70.51 \mathrm{c} \\
(10.94)\end{array}$ & $\begin{array}{c}45.57 \mathrm{E} \\
(0.70)\end{array}$ \\
\hline \multicolumn{13}{|c|}{ Soft white wheat flour } \\
\hline $\begin{array}{c}801.29 \mathrm{~A} \\
(46.42)\end{array}$ & $\begin{array}{c}552.80 \mathrm{a} \\
(9.62)\end{array}$ & $\begin{array}{c}693.10 \mathrm{~B} \\
(47.68)\end{array}$ & $\begin{array}{c}525.54 \mathrm{~b} \\
(15.52)\end{array}$ & $\begin{array}{c}622.36 \mathrm{BC} \\
(29.09)\end{array}$ & $\begin{array}{c}510.22 \mathrm{~b} \\
(5.10)\end{array}$ & $\begin{array}{c}570.72 \mathrm{C} \\
(24.45) \\
\end{array}$ & $\begin{array}{c}501.35 \mathrm{~b} \\
(1.53) \\
\end{array}$ & $\begin{array}{c}416.91 \mathrm{D} \\
(14.12) \\
\end{array}$ & $\begin{array}{c}419.70 \mathrm{c} \\
(10.92)\end{array}$ & $\begin{array}{c}390.37 \mathrm{D} \\
(12.88) \\
\end{array}$ & $\begin{array}{c}397.42 \mathrm{c} \\
(6.25)\end{array}$ & $\begin{array}{c}44.04 \mathrm{E} \\
(0.60)\end{array}$ \\
\hline
\end{tabular}




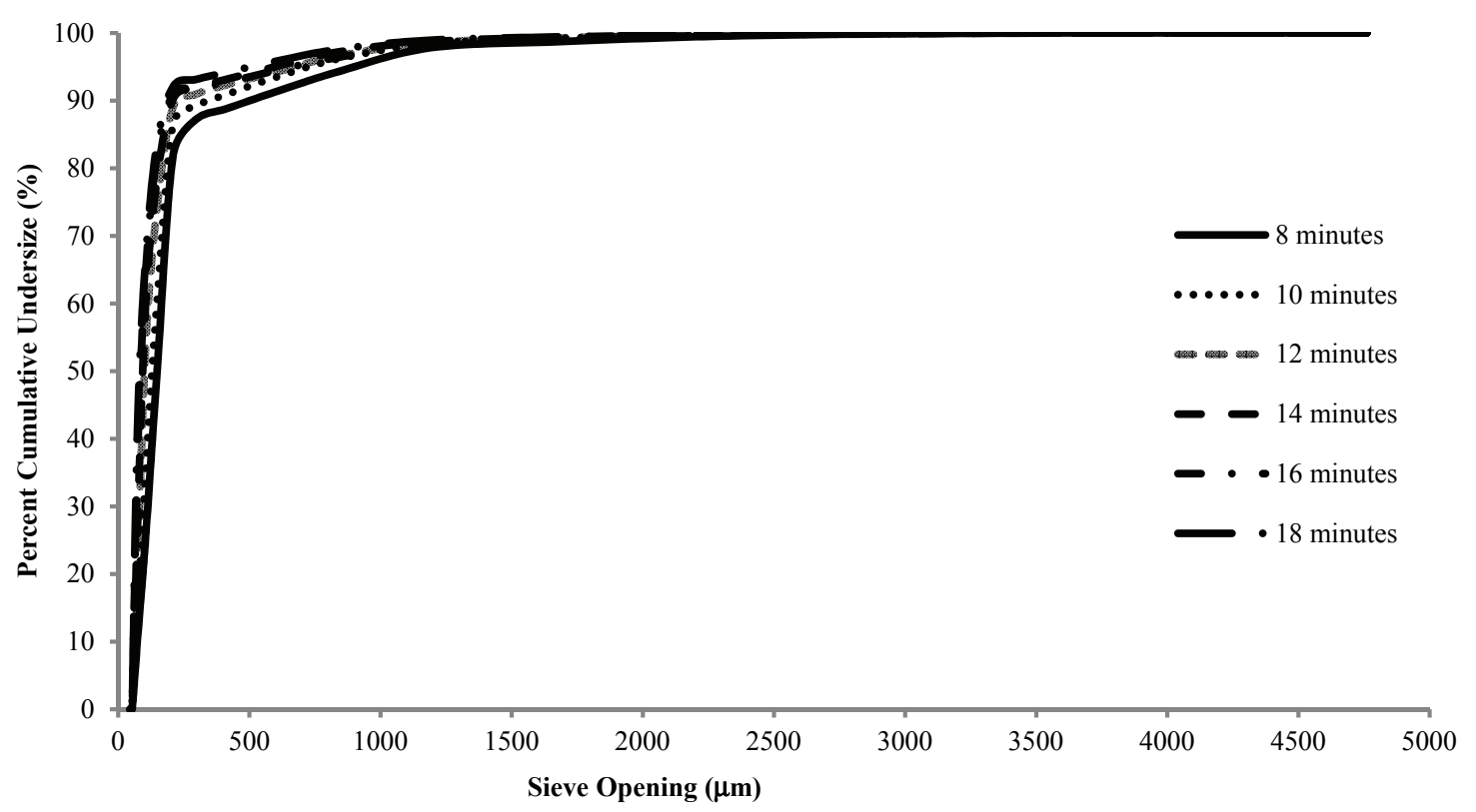

Figure 1. Cumulative distribution of mean particle size for hard red winter wheat flour at different sieving times.

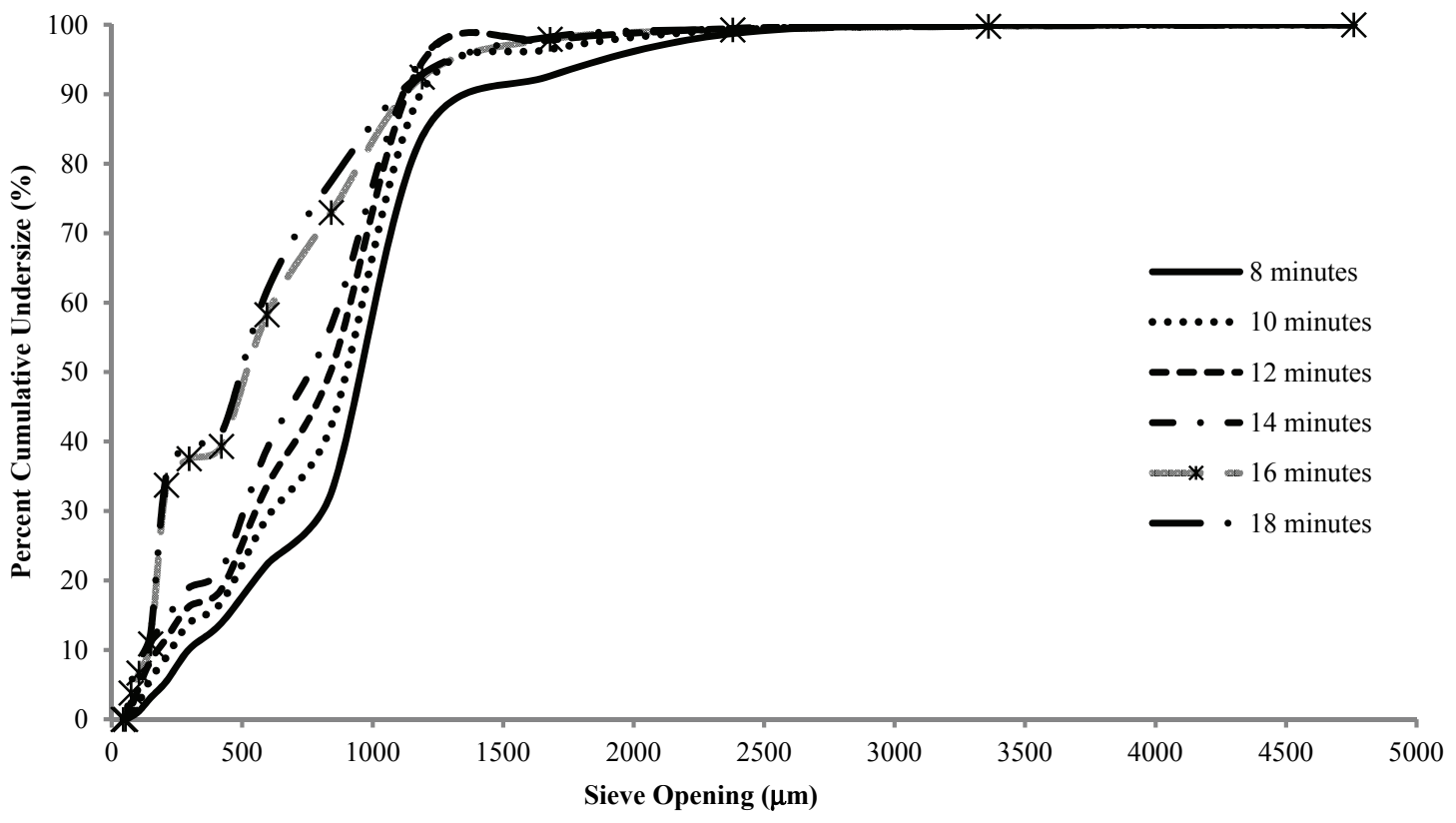

Figure 2. Cumulative distribution of mean particle size for soft white wheat flour at different sieving times.

needed to make the particles flow uniformly. The difference in percent flour retained on each sieve due to the use of a flow agent is shown in figure 3 . The change due to the use of flow agent was highly significant for SW flour and less so for HRW flour. Neel and Hoseney (1984) observed that if the particles of SW wheat flour and HRW wheat flour were reduced to approximately $20 \mu \mathrm{m}$, the surface roughness effect would be removed and the two flours would exhibit similar non-cohesive properties in a Ro-Tap sieve shaker.

There was also a significant difference in particle size $(\mathrm{p}<0.05)$ for HRW flour without a flow agent vs. HRW flour with a flow agent at 14 min sieving time (table 3 ).
This indicates that the results given by the standard method can differ greatly based on the amount of flow agent used. It might be an inappropriate assumption to not require researchers to indicate if a flow agent was used. Particle size analysis showed that there can be a significant variance between wheat classes and that the current official methods for particle size determination (by sieving) might have to be revised when extremely cohesive products are measured. Therefore, there is a need to develop a standard to determine the particle size specifically for flour that clearly indicates the use of a flow agent and the quantity of flour to be used for testing for flours from different wheat classes and varieties. 


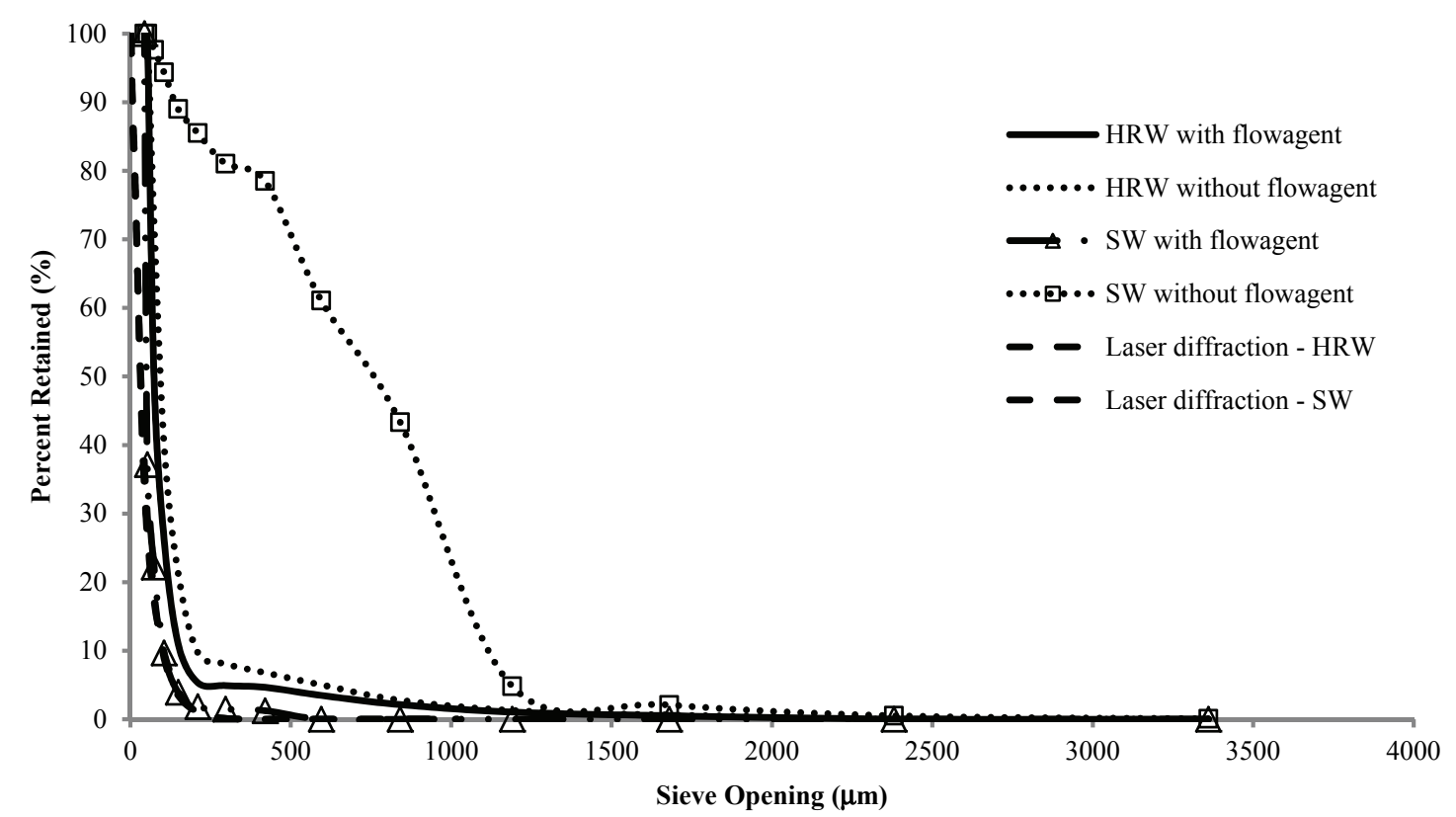

Figure 3. Percent flour retained on each sieve for hard red winter (HRW) and soft white (SW) wheat flour at 14 min of sieving.

Table 3. Geometric mean particle diameter $\left(d_{g_{w}}, \mu \mathrm{m}\right)$ and standard deviation $\left(S_{g_{w}}, \mu \mathrm{m}\right)$ of wheat flour with flow agent. ${ }^{[\mathrm{a}]}$

\begin{tabular}{|c|c|c|c|c|}
\hline \multirow[b]{2}{*}{ Sample } & \multicolumn{2}{|c|}{$\begin{array}{c}\text { With } \\
\text { Flow Agent }\end{array}$} & \multicolumn{2}{|c|}{$\begin{array}{c}\text { Without } \\
\text { Flow Agent }\end{array}$} \\
\hline & $d_{g w}$ & $S_{g w}$ & $d_{g w}$ & $S_{g w}$ \\
\hline Hard red winter wheat flour ${ }^{[b]}$ & $91.33 \mathrm{a}$ & 58.37 & $111.98 \mathrm{~b}$ & 81.05 \\
\hline Soft white wheat flour ${ }^{[\mathrm{c}]}$ & $61.14 \mathrm{a}$ & 26.26 & $570.72 \mathrm{~b}$ & 501.35 \\
\hline
\end{tabular}

[a] Means in the same row followed by the same letter are not significantly different $(\mathrm{p} \geq 0.05)$.

[b] With $0.5 \%$ flow agent.

[c] With $2.5 \%$ flow agent. Soft white wheat was placed on a U.S. No. 40 sieve while sifting

\section{Mathematical Size Distribution FunCtions}

Comparing the cumulative particle size distribution for hard and soft wheat flour showed a more uniform distribution for HRW flour, indicating that the particle sizes are more uniformly distributed. Campbell et al. (2007) also observed that hard wheat flour had a more uniform distribution of particle sizes, unlike soft wheat, which gives a greater proportion of smaller and larger particles and fewer mid-sized particles. The structures of these wheat classes influenced their breakage patterns, resulting in different shapes of their flour particle size distributions (fig. 4). Pre-

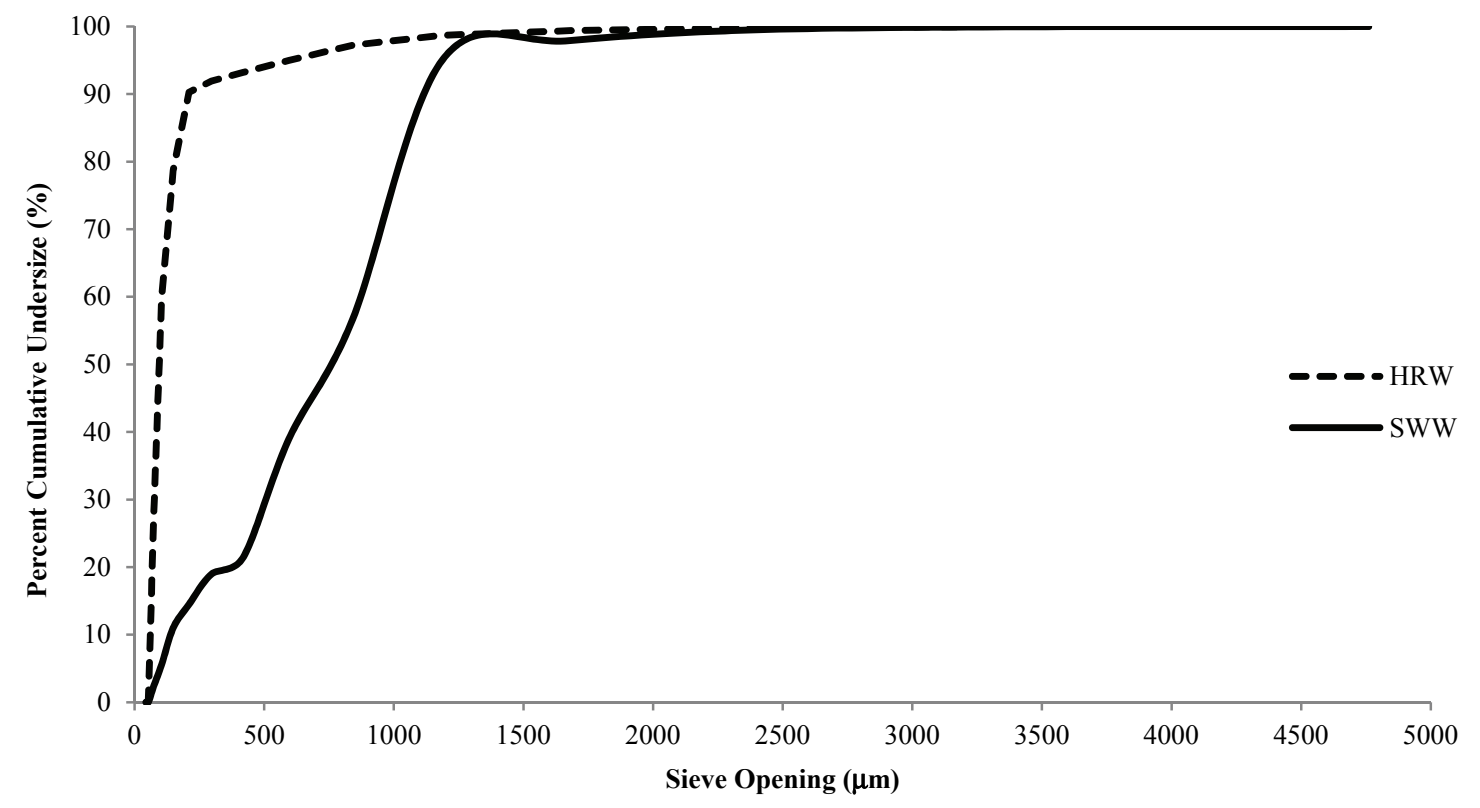

Figure 4. Cumulative particle size distributions of hard red winter (HRW) and soft white (SW) wheat flour after 14 min of sieving. 
Table 4. Parameter estimates of different functions for hard red winter wheat flour and soft white wheat flour at different sieving times. ${ }^{\text {[a }}$

\begin{tabular}{|c|c|c|c|c|c|c|c|}
\hline \multirow[b]{2}{*}{ Sample } & \multirow{2}{*}{$\begin{array}{l}\text { Distribution } \\
\text { Function }\end{array}$} & \multicolumn{6}{|c|}{ Sieving Time } \\
\hline & & $8 \mathrm{~min}$ & $10 \mathrm{~min}$ & $12 \mathrm{~min}$ & $14 \mathrm{~min}$ & $16 \mathrm{~min}$ & $18 \mathrm{~min}$ \\
\hline \multirow{10}{*}{$\begin{array}{l}\text { Hard red winter } \\
\text { wheat flour }\end{array}$} & \multirow[t]{2}{*}{ Log normal } & $\mu=4.91$ & $\mu=4.78$ & $\mu=4.62$ & $\mu=4.55$ & $\mu=4.49$ & $\mu=4.44$ \\
\hline & & $\sigma=0.73$ & $\sigma=0.69$ & $\sigma=0.69$ & $\sigma=0.67$ & $\sigma=0.71$ & $\sigma=0.65$ \\
\hline & \multirow[t]{2}{*}{ Weibull } & $\alpha=1.05$ & $\alpha=1.08$ & $\alpha=1.04$ & $\alpha=1.04$ & $\alpha=0.97$ & $\alpha=1.03$ \\
\hline & & $\beta=204.61$ & $\beta=176.08$ & $\beta=151.04$ & $\beta=139.09$ & $\beta=135.19$ & $\beta=123.9$ \\
\hline & \multirow[t]{4}{*}{ Kumaraswamy } & $\alpha_{1}=0.81$ & $\alpha_{1}=0.78$ & $\alpha_{1}=0.29$ & $\alpha_{1}=0.27$ & $\alpha_{1}=0.27$ & $\alpha_{1}=0.27$ \\
\hline & & $\alpha_{2}=6471.90$ & $\alpha_{2}=57734.00$ & $\alpha_{2}=1.66$ & $\alpha_{2}=1.64$ & $\alpha_{2}=1.76$ & $\alpha_{2}=1.80$ \\
\hline & & $a=44.00$ & $a=44.00$ & $a=44.00$ & $a=44.00$ & $a=44.00$ & $a=44.00$ \\
\hline & & $b=6.55 \mathrm{E}+6$ & $b=1.36 \mathrm{E}+8$ & $b=3913.30$ & $b=3516.00$ & $b=3981.10$ & $b=3851.10$ \\
\hline & \multirow[t]{2}{*}{ Rosin-Rammler } & $n=2.05$ & $n=1.60$ & $n=1.42$ & $n=1.38$ & $n=1.48$ & $n=1.17$ \\
\hline & & $D_{n}=1.09 \mathrm{E}-3$ & $D_{n}=1.89 \mathrm{E}-3$ & $D_{n}=2.17 \mathrm{E}-3$ & $D_{n}=2.32 \mathrm{E}-3$ & $D_{n}=2.12 \mathrm{E}-3$ & $D_{n}=2.84 \mathrm{E}-3$ \\
\hline \multirow{10}{*}{$\begin{array}{l}\text { Soft white } \\
\text { wheat flour }\end{array}$} & \multirow[t]{2}{*}{ Log normal } & $\mu=6.51$ & $\mu=6.37$ & $\mu=6.26$ & $\mu=6.17$ & $\mu=5.86$ & $\mu=5.79$ \\
\hline & & $\sigma=0.65$ & $\sigma=0.70$ & $\sigma=0.75$ & $\sigma=0.79$ & $\sigma=0.89$ & $\sigma=0.89$ \\
\hline & \multirow[t]{2}{*}{ Weibull } & $\alpha=2.0$ & $\alpha=1.96$ & $\alpha=1.89$ & $\alpha=1.75$ & $\alpha=1.31$ & $\alpha=1.28$ \\
\hline & & $\beta=891.71$ & $\beta=786.18$ & $\beta=719.28$ & $\beta=676.83$ & $\beta=537.07$ & $\beta=505.38$ \\
\hline & \multirow[t]{4}{*}{ Kumaraswamy } & $\alpha_{1}=1.99$ & $\alpha_{1}=2.01$ & $\alpha_{1}=1.20$ & $\alpha_{1}=1.81$ & $\alpha_{1}=1.05$ & $\alpha_{1}=0.99$ \\
\hline & & $\alpha_{2}=655.43$ & $\alpha_{2}=557.58$ & $\alpha_{2}=38.15$ & $\alpha_{2}=491.13$ & $\alpha_{2}=15.94$ & $\alpha_{2}=2.26 \mathrm{E}+6$ \\
\hline & & $a=4.3$ & $a=-16.10$ & $a=44.00$ & $a=-13.71$ & $a=43.92$ & $a=44.00$ \\
\hline & & $b=23072.00$ & $b=18711.00$ & $b=14422.00$ & $b=21436.00$ & $b=6708.40$ & $b=1.19 \mathrm{E}+9$ \\
\hline & \multirow[t]{2}{*}{ Rosin-Rammler } & $n=2.31$ & $n=0.09$ & $n=1.61$ & $n=1.52$ & $n=1.38$ & $n=1.32$ \\
\hline & & $D_{n}=7.04 \mathrm{E}-4$ & $D_{n}=7.89 \mathrm{E}-4$ & $D_{n}=8.45 \mathrm{E}-4$ & $D_{n}=9.05 \mathrm{E}-4$ & $D_{n}=1.10 \mathrm{E}-3$ & $D_{n}=1.18 \mathrm{E}-3$ \\
\hline
\end{tabular}

viously, Mateos-Salvador et al. (2011) predicted the breakage behavior of wheat during first break milling and found that the normalized Kumaraswamy breakage function was a successful technique for predicting the size distribution of first break wheat, although there were minor discrepancies in prediction.

For HRW flour (table 4), the size or shape parameter for each of the distributions decreased with increase in sieving time, except for the Weibull distribution, which did not change with time. For SW flour, the Weibull shape parameter $(\alpha)$ and the mean value for the log-normal distribution decreased with increased sieving time. The size parameter for the Rosin-Rammler distribution function increased with sieving time from 10 to $12 \mathrm{~min}$, but the parameter value decreased with further increase in time. For SW flour (table 4), the Weibull, log-normal, and Rosin-Rammler estimates were more accurate than the Kumaraswamy function parameters.

Figures 5 and 6 show the Kumaraswamy, log-normal, Weibull, and Rosin-Rammler distributions for both wheat flour classes at 18 min sieving time plotted with the measured size distribution. A noticeable difference was observed in the log-normal and Weibull size distributions compared to the Kumaraswamy and Rosin-Rammler size distributions. The percent deviation from the measured size distribution was low for the Weibull and log-normal distribu-

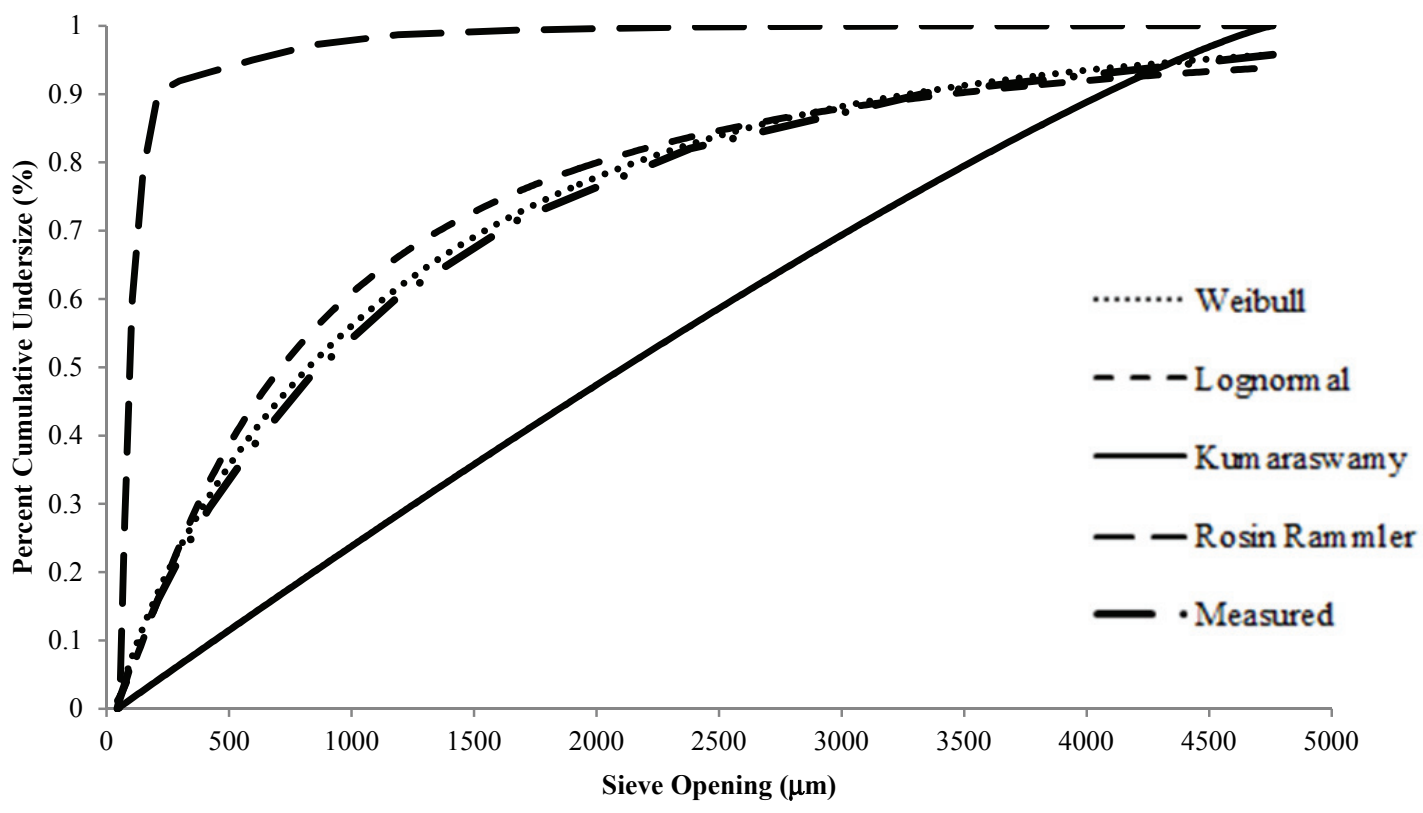

Figure 5. Mathematical size distribution of hard red winter wheat flour at $18 \mathrm{~min}$ of sieving. 


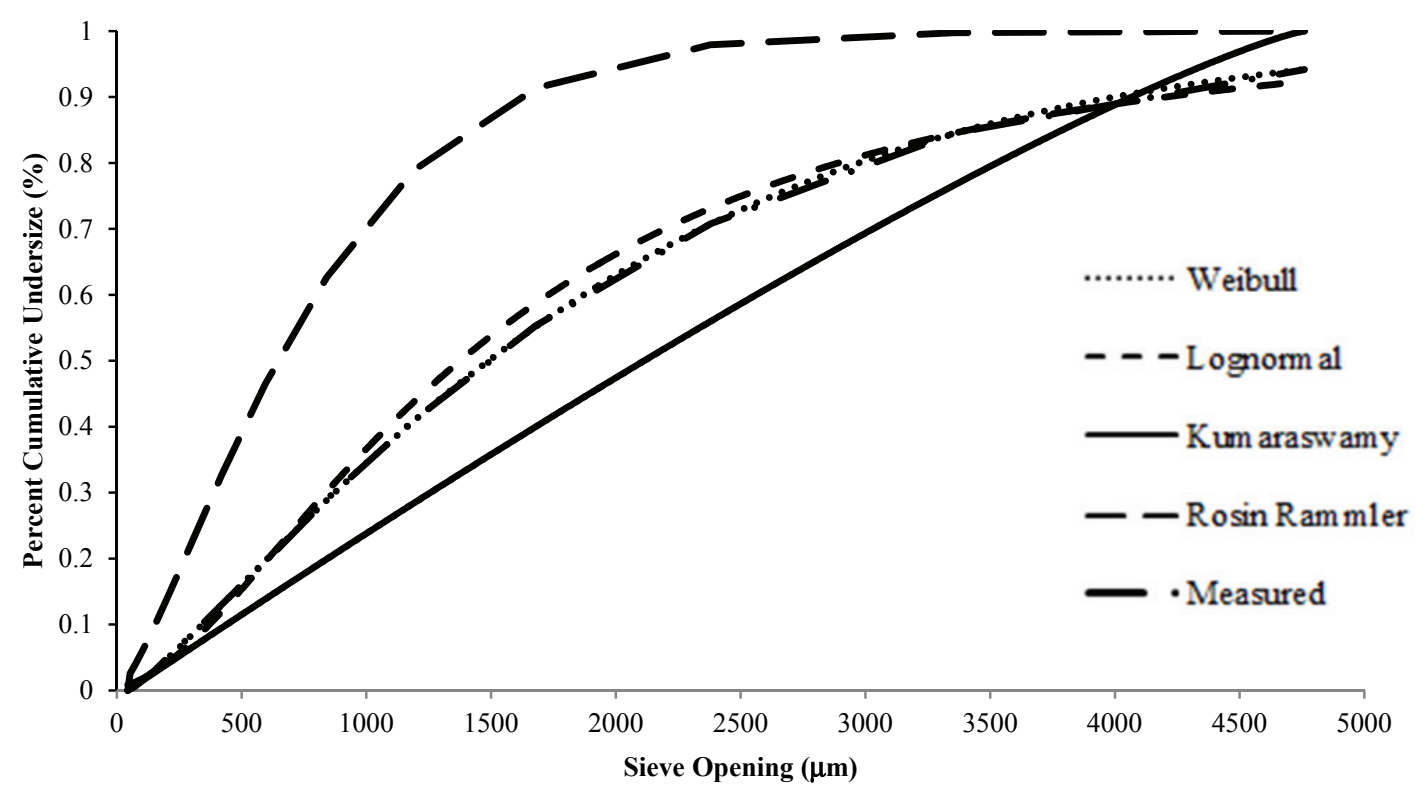

Figure 6. Mathematical size distribution of soft white wheat flour at $18 \mathrm{~min}$ of sieving.

Table 5. Percent relative deviation $(P, \%)$ of actual particle size distribution from mathematical prediction.

\begin{tabular}{|c|c|c|c|c|c|c|c|}
\hline \multirow[b]{2}{*}{ Sample } & \multirow{2}{*}{$\begin{array}{l}\text { Distribution } \\
\text { Function }\end{array}$} & \multicolumn{6}{|c|}{ Sieving Time } \\
\hline & & $8 \mathrm{~min}$ & $10 \mathrm{~min}$ & $12 \mathrm{~min}$ & $14 \mathrm{~min}$ & $16 \mathrm{~min}$ & $18 \mathrm{~min}$ \\
\hline \multirow{4}{*}{$\begin{array}{l}\text { Hard red winter } \\
\text { wheat flour }\end{array}$} & Log-normal & 47.80 & 47.27 & 46.25 & 45.72 & 45.29 & 45.10 \\
\hline & Weibull & 47.46 & 47.21 & 46.62 & 46.38 & 45.90 & 45.83 \\
\hline & Kumaraswamy & 61.25 & 61.66 & 62.00 & 62.13 & 62.15 & 64.57 \\
\hline & Rosin-Rammler & 214.99 & 167.78 & 122.78 & 123.70 & 92.97 & 49.25 \\
\hline \multirow{4}{*}{$\begin{array}{l}\text { Soft white } \\
\text { wheat flour }\end{array}$} & Log-normal & 53.71 & 57.60 & 55.86 & 54.63 & 48.85 & 49.48 \\
\hline & Weibull & 51.10 & 54.44 & 54.02 & 51.21 & 50.47 & 50.44 \\
\hline & Kumaraswamy & 33.33 & 36.04 & 44.97 & 48.87 & 54.75 & 56.03 \\
\hline & Rosin-Rammler & 114.76 & 103.36 & 96.46 & 84.90 & 73.20 & 61.98 \\
\hline
\end{tabular}

tions compared to the Kumaraswamy and Rosin-Rammler distributions (table 5) for HRW flour. For SW flour, at up to 14 min of sieving time, the Kumaraswamy model gave a better prediction than the other models. For all the prediction equations, the percent relative deviation decreased with increase in sieving time. Similar to the observations during the experimental trials, a decrease in relative deviation indicates that the resultant size distribution depends on the sieving time, so finding an optimized time is important for prediction purposes.

\section{CONCLUSiOnS}

The effect of sieving time on the average particle size and size distribution of wheat flour from two wheat classes that highly differ in hardness was studied. Sieving time had a significant effect on the measured average particle size for both HRW and SW wheat flours. Due to cohesion, the measured average particle size was higher at low sieving duration, and increases in sieving time helped to break the particle bonds and thus reduce the average particle size. This study indicated that the sieving time (for particle size analysis) should be optimized based on the class of wheat and that standard measurements would result in inaccurate results. Results from this study found a significant difference $(p<0.05)$ in measured particle size between sieving times of 8 and 18 min, suggesting that there might be a need either to re-evaluate the recommended sieving times for all wheat flours or to classify certain flours as cohesive and establish a longer sieving time. It can be argued that the use of a flow agent provides a more accurate evaluation of a cohesive sample's particle size by facilitating the movement of particles through the screens, compared with not using a flow agent. Because there was no standardized percent use of a flow agent for wheat flour (based on wheat class), further intensive studies are required to find the optimum amount of flow agent that needs to be added to wheat flour for accurate particle size measurement.

\section{REFERENCES}

AACC. (2011). 55-60.01: Guideline for determination of particle size distribution. St. Paul, Minn.: AACC International.

Alderliesten, M. (2013). Mean particle diameters: Part VII. The Rosin-Rammler size distribution: Physical and mathematical properties and relationships to moment-ratio defined mean particle diameters. Particle and Particle Systems Characterisation, 30(3), 244-257. http://dx.doi.org/10.1002/ppsc.201200021.

AOAC. (2000). 925.10: Solids (total) and moisture in flour-Air oven method. In Official Methods of Analysis. 17th ed. Gaithersburg, Md.: AOAC International.

ASABE Standards. (2008). S319.4: Method of determining and 
expressing fineness of feed materials by sieving. St. Joseph, Mich.: ASABE.

Bechtel, D. B., Zayas, I., Dempster, R., \& Wilson, J. D. (1993). Size distribution of starch granules isolated from hard red winter and soft red winter wheats. Cereal Chem., 70(2), 238-240.

Campbell, G. M., Bunn, P. J., Webb, C., \& Hook, S. C. (2001). On predicting roller milling performance: Part II. The breakage function. Powder Tech., 115(3), 243-255. http://dx.doi.org/ 10.1016/S0032-5910(00)00349-1.

Campbell, G. M., Fang, C., \& Muhamad, I. I. (2007). On predicting roller milling performance: Part VI. Effect of kernel hardness and shape on the particle size distribution from first break milling of wheat. Food and Bioproduct Proc., 85(1), 7-23. http://dx.doi.org/10.1205/fbp06005.

CFR. (2013). 21 CFR 137.105: Requirements for specific standardized cereal flours and related products. Washington, D.C.: Code of Federal Regulations.

Hareland, G. A. (1994). Evaluation of flour particle size distribution by laser diffraction, sieve analysis, and near-infrared reflectance spectroscopy. J. Cereal Sci., 20(2), 183-190. http://dx.doi.org/ 10.1006/jcrs.1994.1058.

Irani, R. R., \& Fong, W. S. (1961). Measurements of the particle size distribution of flour. Cereal Chem., 38(1), 67-75.

Khazaei, J., Jafari, S., \& Noorolah, S. (2008). Log-normal vs. normal and Weibull distributions for modeling the mass and size distribution of sunflower seed and kernels. Proc. World Conf. on Agricultural Information and IT, 7-16. International Association of Agricultural Information Specialists (IAALD), and Asian Federation of Information Technology in Agriculture (AFITA).

Kim, W., Choi, S. G., Kerr, W. L., Johnson, J. W., \& Gaines, C. S. (2004). Effect of heating temperature on particle size distribution in hard and soft wheat flour. J. Cereal Sci., 40(1), 9-16. http://dx.doi.org/10.1016/j.jcs.2004.04.005.

Limpert, E., Stahel, W. A., \& Abbt, M. (2001). Log-normal distribution across the sciences: Keys and clues. Bioscience, 51(5), 341352. http://dx.doi.org/10.1641/0006-3568(2001)051[0341: LNDATS]2.0.CO;2.

Lineback, D. R., \& Rasper, V. F. (1988). Wheat carbohydrates. In Wheat: Chemistry and Technology, Vol. 1, 277-287. 3rd ed. Y.
Pomeranz, ed. St. Paul, Minn.: AACC.

Lu, J. Z., Monlezun, C. J., Wu, Q., \& Cao, Q. V. (2007). Fitting Weibull and log-normal distributions for medium-density fiberboard and wood particle length. Wood and Fiber Sci., 39(1), 8294.

Martin, J. M., Frohberg, R. C., Morris, C. F., Talbert, L. E., \& Giroux, M. J. (2001). Milling and bread baking traits associated with puroindoline sequence type in hard red spring wheat. Crop Sci., 41(1), 228-234. http://dx.doi.org/10.2135/ cropsci2001. $411228 \mathrm{x}$.

Mateos-Salvador, F., Sadhukan, J., \& Campbell, G. M. (2011). The normalised Kumaraswamy breakage function: A simple model for wheat roller milling. Powder Tech., 208(1), 144-157. http://dx.doi.org/10.1016/j.powtec.2010.12.013.

Neel, D. V., \& Hoseney, R. C. (1984). Sieving characteristics of soft and hard wheat flours. Cereal Chem., 61(4), 259-261.

Nielsen, R. H., Harnby, N., \& Wheelock, T. D. (1982). Mixing and circulation in fluidized beds of flour. Powder Tech., 32(1), 7186. http://dx.doi.org/10.1016/0032-5910(82)85008-0.

Onwulata, C. I., Konstance, R. P., \& Holsinger, V. H. (1996). Flow properties of encapsulated milkfat powders as affected by flow agent. J. Food Sci., 61(6), 1211-1215. http://dx.doi.org/10.1111/ j.1365-2621.1996.tb10962.x.

Pauly, A., Pareyt, B., Fierens, E., \& Delcour, J. A. (2013). Wheat (Triticum aestivum L. and T. turgidum L. ssp. Durum) kernel hardness: II. Implications for end-product quality and role of puroindolines therein. Comp. Rev. Food Sci. and Food Safety, 12(4), 427-438. http://dx.doi.org/10.1111/1541-4337.12018.

Sullivan, B., Engebreston, W. E., \& Anderson, M. L. (1960). The relation of particle size of certain flour characteristics. Cereal Chem., 37(4), 436-455.

Turnbull, K. M., \& Rahman, S. (2002). Endosperm texture in wheat. J. Cereal Sci., 36(3), 327-337. http://dx.doi.org/10.1006/ jcrs.2002.0468.

Weibull, W. (1951). A statistical distribution function of wide applicability. J. Appl. Mechanics, 18(3), 293-297.

Wu, Y. V., Stringfellow, A. C., \& Bietz, J. A. (1990). Relation of wheat hardness to air-classification yields and flour particle size distribution. Cereal Chem., 67(5), 421-427. 